\title{
'DON'T YOU LIKE ME? AM I UGLY? OR DON'T I SPEAK WELL?' ANALYSIS OF DISAGREEMENT AND EMOTIONAL EXHIBITION IN THE EMAILS OF CHINESE UNIVERSITY STUDENTS OF SPANISH ${ }^{1}$
}

\author{
"¿NO ME QUIERES? ¿SOY FEA? O ¿NO HABLO BIEN?" ANÁLISIS \\ DEL DESACUERDO Y LA EXPOSICIÓN EMOCIONAL EN LOS \\ CORREOS ELECTRÓNICOS DE ESTUDIANTES UNIVERSITARIOS \\ CHINOS DE ESPAÑOL
}

\author{
DAVID RODRÍGUEZ VELASCO \\ Queen's University Belfast \\ d.rodriguez-velasco@qub.ac.uk \\ MARÍA CECILIA AINCIBURU \\ Universidad Nebrija de Madrid y Universitá di Siena (Italia) \\ caincibu@nebrija.es y ainciburu@unisi.it
}

\begin{abstract}
The speech act of disagreement is an area that has received scant attention in the field of interlanguage pragmatics. However, in academic communication the strategies employed in this act of speech precede the development of an argument, a textual genre that is considered central to scholastic positioning. The less equitable the power relationship between the parties (between peers, between teacher and group of students, etc.), the stronger the illocutive intensity of this act. This study aims to investigate the strategies used in an unequal situation (student/lecturer) by Chinese learners of Spanish as a second language in order to perform the speech act of disagreement in their second language. Data relating to 149 Chinese university students were gathered by means of a pedagogical framework-based task in which they had to write an email to their lecturer expressing their disagreement. To identify their sociopragmatic knowledge in a digital environment and its adequacy in an academic Spanish context, the microstructure of their writings was examined for pragmatic moves related to politeness and level of directness. Our results suggest that the Chinese students analysed in the study did not adjust to an appropriate register or manner in academic Spanish.
\end{abstract}

${ }^{1}$ This study is part of the project: "Emotion, memory, linguistic identity and emotional acculturation: Their influence on the learning of Spanish as a language of migration (EMILIA)" (Ref. FFI2017-83166-C2-2-R, R+D+i Projects, of the State Program for Research, Development and Innovation Oriented to the Challenges of Society, Government of Spain). 
Keywords: Negative politeness, disagreement, academic discourse, Chinese, Spanish as a Foreign Language, emotions.

\section{RESUMEN}

El discurso del desacuerdo es un área que ha recibido poca atención en el campo de la pragmática de la interlengua. Sin embargo, en la comunicación académica, las estrategias empleadas en este acto de habla preceden al desarrollo de un argumento, un género textual que se considera central para el posicionamiento escolar. Cuanto menos equitativa sea la relación de poder entre las partes (entre pares, entre el maestro y el grupo de estudiantes etc.), mayor será la intensidad ilocutiva de este acto. Este estudio tiene como objetivo investigar las estrategias utilizadas por los estudiantes chinos de español L2 en una situación de desigualdad (estudiante/profesor) para realizar el acto de desacuerdo en su segundo idioma. Los datos relacionados con 149 estudiantes universitarios chinos se obtuvieron mediante una tarea basada en un marco pedagógico en la que tuvieron que escribir un correo electrónico a su profesor expresando su desacuerdo. Para identificar su conocimiento sociopragmático en un entorno digital y su adecuación en un contexto académico español, se examinó la microestructura de sus escritos en busca de movimientos pragmáticos relacionados con la cortesía y el grado de dirección. Nuestros resultados sugieren que los estudiantes chinos analizados en el estudio no se ajustaron a un registro o una forma apropiada en el español académico.

Palabras clave: Cortesía negativa, desacuerdo, discurso académico, chino, Español como Lengua Extranjera, emociones.

Recibido: 25/03/2020. Aceptado: 07/05/2020.

\section{INTRODUCTION: DISAGREEMENT IN ACADEMIC CONTEXT}

$\mathrm{O}$ ver the past 15 to 20 years, universities have been providing institutional email addresses to students, faculty, and staff to facilitate communication within the institution. This new means of communication makes teachers far more accessible than they used to be back when the only way to talk to them was by meeting them during office hours. Academics have studied the phrasing that email users tend to employ in this context, especially in English, and found that its style is similar to that traditionally adopted in letters. These studies have also contextualised requests or apologies as speech acts (Chen, C. 2006; BiesenbachLucas, 2006, 2007; Siu, 2008; Woodfield and Economidou-Kogetsidis, 2010; Tseng, 2015; Chang, Curran, Hsu and Hsu, 2016). By contrast, this study focuses on the act of disagreement in Chinese students' emails, in accordance with the above findings on the way they articulate them. 
This research aims to analyse these emails, written in Spanish as a foreign language, to contextualise the act of dissent. In a university context, the act of dissent is a step prior to issuing a counterargument, and it is thus an illustrative example of the academic culture in which it takes place (Walker, 2011; Ainciburu, 2018). Since the first studies on intercultural courtesy the analysis of dissent was carried out taking the purpose of each interaction into consideration (Brown and Levinson ([1978] 1987); Kerbrat-Orecchioni, 1997). To achieve this, researchers used some of the patterns that emerged from speech acts and others that resulted from more recent studies (Chen, M. 2006; Xuehua, 2006; Brenes-Peña, 2011; Yan, 2016). They did so with the intention of not reducing the analysis to a single sentence, but rather to observe certain co-occurrences. There have not been many studies on dissention in Chinese academic language and there is no evidence of any such studies in Spanish as a foreign language. In addition, research on English as a foreign language is often based on discourse completion tasks (DCTs) rather than on pedagogical tasks.

Academics undertook these studies as they saw how momentously and consistently modes of communication have changed in universities. Information provided by Spanish universities indicates that there are more than 500 agreements with Chinese institutions, and it is estimated that each year some 35,000 students specialise in Spanish as a foreign language in mainland China, Taiwan, and Hong Kong (Claudio-Quiroga, 2017). This number is constantly increasing, as it is in Latin American countries as well, and so are the stories of misunderstandings between university teachers and exchange students (Hu, Van Veen and Corda, 2016).

\section{GENERAL STRATEGIES FOR DISAGREEMENT}

In pragmatics, disagreement is often used as a blanket term that encompasses multiple concepts. It implies a verbal or non-verbal stance of opposition. Brenes-Peña (2011: 65) characterises disagreement as a "discursive motion of response denying the validity of the propositional content held by another interlocutor without at any time incorporating a denigration of his person or his speech". Her study is based on the analysis of colloquial debates in Spanish in which she has seen that the verbal expression of disagreement implies the undermining of the speaker. This can be problematic, considering the uneven power dynamic that exists between a student and a teacher.

Moreover, in pragmatics, dissenting acts are regarded as a response and not as an initiatory act. In other words, a disagreement is a negative reaction to an opinion that has previously been formulated by another party. In the realm of conversation analysis, Sacks (1987 [1973]) considers that both conformity and design acts are parts of an adjacency pair, where the first part is an opinion or as- 
sessment expressed with the expectation of a response, which can either be a form of agreement or of dissent.

On the one hand, research within the realm of politeness theory (the perspective based on Brown and Levinson ([1978] 1987) seeks to establish a theoreticalanalytical framework to identify the level of courtesy in language. It does so by establishing a relationship between the explicit form of the linguistic act and the 'illocutive force'. According to this paradigm, a communicative and interactional act can be considered direct when there are specific elements that directly relate the statement to the intention of the speaker from a lexical or syntactic-semantic point of view (Locher and Graham, 2010). For example, if a lecturer comments, 'It's a pretty easy test, right?', and the students replies, 'Not really', that would be considered as a direct act of disagreement, since the word 'not' conveys opposition to the statement produced by the professor. If, by contrast, the reply was, 'Do you think so?' then the student would be questioning the lecturer's opinion without contrasting it, but this would entail a response which indirectly expresses disagreement.

Therefore, according to Brown and Levinson ([1978] 1987), all human beings use a series of verbal strategies that allow them to preserve their public image while respecting the image of others. This concept can be described in terms of two complementary factors: 'positive' and 'negative'. The first designates the positive self-image that the individual has of himself or herself, which aims to be recognised and reinforced by other members of society. The second concerns the desire everyone has to ensure that his or her actions are not compromised by others.

Based on the definition of disagreement, the phenomenon of positive or negative courtesy, and the possibility of expression through 'direct' or 'indirect' acts, Rees-Miller (2000) analyses a discussion in a university linguistics class on the basis of the four resulting categories: disagreement not softened (direct), softened disagreement with positive politeness, softened disagreement with negative politeness, and aggravated disagreement (intensified). To account for the lack of agreement in Chinese, Xuehua (2006) proposes five possible strategies to communicate disagreement using a DCT.

These categories of analysis do not differ from those previously used by Brown and Levinson ([1978] 1987) or by Kerbrat-Orecchioni (1997). However, they add the category of omission, which is more likely to be found in DCTs than in conversation analysis. The strategies presented in Table I relate to empirical data of Chinese students, which is discussed further on in the article. 
Table I. Five strategies of realizing disagreement (based on Xuehua, 2006: 57).

\begin{tabular}{|l|l|}
\hline Types of strategies & Definition \\
\hline Direct strategy & $\begin{array}{l}\text { Expressing disagreement directly and boldly } \\
\text { without redressive action; having the most } \\
\text { serious face threat, like counterattack, } \\
\text { sarcasm, direct disagreement, contradiction, } \\
\text { and so on. }\end{array}$ \\
\hline Negative politeness strategy & $\begin{array}{l}\text { Oriented to the hearer's negative face, like } \\
\text { accounting, mitigating, and rhetorical } \\
\text { questions. }\end{array}$ \\
\hline Positive politeness strategy & $\begin{array}{l}\text { Oriented to the hearer's positive face, like } \\
\text { partial agreement, pseudo-agreement, and } \\
\text { conditioned agreement. }\end{array}$ \\
\hline Hinting strategy & $\begin{array}{l}\text { Implicitly expressing disagreement, like } \\
\text { hints, and positive comment. }\end{array}$ \\
\hline Avoidance strategy & $\begin{array}{l}\text { Make non-commitment on the others } \\
\text { opinions. }\end{array}$ \\
\hline
\end{tabular}

Face-threatening speech acts are usually understood as a sequence of semantic formulas or realization strategies (Chen, M. 2006: 23). According to Brenes-Peña (2011), an expert in the study of disagreement among native Spanish speakers, the best way to classify disagreement expressions is through their argumentative functions.

In her literature review, she points out that the following pragmatic strategies and semantic formulas have functions associated with disagreement because of their shared linguistic features: account, challenges, clarification, contradictions, correction, counterclaims, criticism, defense, empathy, evasion, gratitude, irrelevancy claims, justification, partial agreement, positive remarks (or positive statement), postponement of decision, refraining from expressing opinion, suggestion, and token agreement. Some of these categories may have a questionable label; 'partial agreement', for example, might not be strictly considered a function, but an indirect form of disagreement. Other categories seem to overlap, or do not clearly correspond to possible linguistic functions, such as 'postponement of decision'. Unlike the strategies of disagreement based on the theoretical framework offered by Brown and Levinson ([1978] 1987), such as those of Rees-Miller (2000) and Xuehua (2006), those of Brenes-Peña (2011), although debatable in their relevance, open up the possibility of considering aspects related to subjectivity and emotionality -empathy and gratitude, for example- which can be expressed with more or less direct strategies, with a greater or lesser degree of attenuation. The 
analysis of Brenes-Peña's native conversation is qualitative and does not talk about the frequency of these formulas, and it would therefore be helpful to investigate the semantic formulas associated with disagreement in the Spanish language.

There are situations in which disagreement is the norm, based on the social expectations in interpersonal communication. In political debates, for example, each debater maintains his or her own position and does not expect to reach an agreement, rather aspiring to make persuasive arguments. In discussions between friends or spouses who have already made their position clear on a certain subject, they maintain their position despite the fact that they end up discussing it multiple times throughout the relationship. These cases are usually studied in relation to what is called 'strong disagreement'. In the case of native Mandarin speakers, Zhu (2014) demonstrates that, in situations of formal discussion with strong disagreement, the interlocutors construct opposing discourses without the manifestation of reactions or signs of 'loss of face', as if it were the very situation that suspends the criteria of acceptability of a trial. Mitigation does not seem to be particularly necessary, as if the speakers, called upon to dissent, would allow themselves to formulate direct acts without experiencing their force as miseducation. It is possible that these situations are linked to rituality to a significant degree, and that they can be more easily understood through conversation analysis. This reflection on the meaning of the act of disagreement applies best to situations of parity between interlocutors, suspending the perlocutive force of the speech act. However, this concept may still be valid even in the case of asymmetrical relationships, such as those between teacher and students.

\section{EMPIRICAL STUDIES ON SECOND LANGUAGE DISAGREEMENT}

In this paper we aim to examine the way in which Chinese students disagree in Spanish. Therefore the review carried out on the literature on native speakers although necessary to focus the contrast between the act of speaking in Spanish and in Chinese or to hypothesise the linguistic transfer- may not be completely adequate to describe the phenomenon. Rees-Miller (2000) examines the act of disagreement in university settings. He conducts this study by examining the choice of English linguistic markers used to mitigate or reinforce disagreement and demonstrates the complexity of factors that influence this choice. In asymmetrical power dynamics between lecturers and students, lecturers tend to use a greater number of positive courtesy strategies (more humour, positive comments, and inclusive pronouns) to encourage students to participate actively in class. Conversely, when the student disagrees with the teacher there is only one example of downtoner negative courtesy ('That's not entirely true...') and no examples of aggravated disagreement. However, the results have been examined because 
they reveal a greater tendency to use positive courtesy in the case of asymmetric relationships.

Observers from other cultures have studied linguistic expressions in Chinese with perplexity. Günthner (1993), an English lecturer at a Chinese university, makes reference to the use of the formula 'Have you dined?' or 'Have you eaten?' as a formulaic greeting, to which a polite interlocutor should reply 'Yes, I have been selfish'. $\mathrm{Hu}$ (1944) indicates that in the Chinese language there are two concepts that translate into the pragmatic concept of image or face: '面子 mianzi', the reputation or prestige that a person can build through his or her performance in a society, and '臉 lian', the trust a society has in the integrity of a person's moral character $(\mathrm{Hu}$, 1944: 45). Mao (1994: 459) argues that today the 'image' involves "an interactional orientation on the part of the individual speaker toward establishing connectedness to, and seeking interpersonal harmony with, one's own community".

Two studies on the disagreement of Mandarin Chinese-speaking university students are more closely related to our research. In both cases, the foreign language studied is English and the data is elicited using DCTs. In her doctoral thesis, Chen, M. (2006) studies the speech act of disagreement made by 120 Chinese English as a Foreign Language (EFL) speakers in Taiwan and 120 native English speakers, using the categorization presented in Table II. As in many of the studies reviewed, it may seem curious that the first category of dissent is categorised as 'no disagreement'.

Table II. Disagreement Strategies in M. Chen's research (Chen, M., 2006: 40).

\begin{tabular}{|l|l|}
\hline Main strategies of disagreement & Subcategories \\
\hline \multirow{2}{*}{ 1. No disagreement } & Opt out \\
\cline { 2 - 2 } & Agreement \\
\cline { 2 - 2 } & Avoidance \\
\hline \multirow{2}{*}{ 2. Indirect disagreement } & Indirect refusal \\
\cline { 2 - 2 } 3. Direct disagreement & Suggested opinion \\
\hline \multirow{4}{*}{$4 . \quad$ Positive remarks } & Contradiction \\
\cline { 2 - 2 } & Direct refusal \\
\hline \multirow{2}{*}{} & Partial agreement \\
\cline { 2 - 2 } & Gratitude \\
\cline { 2 - 2 } & Apology \\
\cline { 2 - 2 } & Empathy \\
\cline { 2 - 2 } & Consideration \\
\hline
\end{tabular}


Results that consider the variable of 'distance' demonstrate that English speakers, who represent a more individualistic culture, tend to be less aware of social hierarchies. Conversely, Chinese speakers tend to be more sensitive when it comes to identifying situations of unequal status, which is a common trait in collectivist cultures. In terms of the type of strategies, both groups use more direct strategies in symmetrical situations and use indirect forms more frequently when there is power asymmetry. In simulated situations of the DCT in which the student must express disagreement with the teacher, distance is often used as an explicit argument to reduce the level of directness of the disagreement. ‘大概會先認為自己才疏學淺吧! ’’ ['I would think I'm weak in my profession']. Only Chinese L1 students tended to agree with their superiors more than their equals. The data can be seen to confirm Gu's statement (1990) that in the "hierarchical system from old China the Chinese would choose to agree, keep silent or avoid disagreement to show their deference when they hold oppositional opinions with the higher status". Gumina (2018: 218) argues that this hierarchical factor is so pervasive in Chinese culture that it defines even the power relations in the educational and political system, and when considering the status of the various languages that make up the country's multilingual mosaic. By contrast, the English speakers were more verbally expressive by using more 'contradiction' in conjunction with various and original positive remarks.

As for Chinese English learners, Chen, M. (2006) hypothesises that there is a classic 'interlingua' effect. Low-level students produce forms of disagreement that are closer to those of Chinese, while higher-level students in English are closer to forms of disagreement typically produced by native English speakers. The pragmatic transfer effect, the widespread use of 'avoidance' in asymmetrical situations and 'contradiction' in symmetrical situations, is most evident in students with lower performance. On the other hand, high-level speakers tried to demonstrate their mastery of the foreign language by using strategies that are quite unusual in Chinese, such as "challenge to the interlocutor" (Chen, M. 2006: 149).

In pragmatic terms, both the act of dissent and the faculty of lying to conceal a wrongdoing can demonstrate crucial differences between social groups (between North Americans and Chinese, in Chen, Chunmei and Lin, 2013). While studying the act of disagreement -either using DCTs or simulations- it may be impossible to elicit data that could verify the truthfulness of the arguments provided with the act of disagreement. Xuehua (2006) studies two small groups of Chinese English learners, with low and high proficiency levels in foreign languages, who respond to DCT written simulations in situations of disagreement, with asymmetric and symmetrical forms of relationship, and in public and private settings.

Recently, Yan (2016) has partially replicated Xuehua's (2006) study with DCT by contrasting the disagreement of 35 Americans and 42 Chinese English students in different scenarios. The second scenario verifies the situation that inter- 
ests us: "In class when your teacher is explaining how to solve a problem, you find the teacher's solution is not correct and you don't agree with her. What do you say to your teacher?” Yan (2016: 234). In this case, as in Xuehua (2006), no corpus is presented, and the analysis is purely quantitative. The results demonstrate that the most frequently used strategy by the Chinese students is the negative courtesy (54.29\%), which contrasts significantly with all the others (direct, implicit, and avoidance strategies receive the same percentage value, 14.29\%, while positive courtesy strategies receive $2.86 \%$ ). The greatest contrast between groups is in the mode of addressing the teacher ('Mr/Ms + last name.'/'Teacher') and not in the type of strategy used. The result does not coincide with that of Xuehua (2006), and since it is not possible to access the corpus data it is difficult to understand whether they are different scenarios or a different tagging of the corpus. It is most likely that this is a problem linked to the situation of cultural immersion in which the students studied by Yan (2016) find themselves, which brings our research closer to that of Chen, M. (2006) and Xuehua (2006).

The aim of this study is to obtain empirical data that can characterize the disagreement of Chinese students when they write emails in Spanish as a foreign language. Since there is little or no data for Spanish in particular, we must compare them with those obtained by the authors reviewed in the previous paragraph. Based on these results, we should expect a preference for indirect acts and a lack of explicit disagreement (Chen, M. 2006; Xuehua, 2006), as well as the possibility of remarks caused by collaboration or positive emotions such as gratitude and empathy (Chen, M. 2006). We do not know whether the idiosyncrasies of Spanish -considered by the Chinese as representing a freer culture- can change the courtesy uses of native acting.

\section{RESEARCH METHOD}

The current study examines dissenting email communication between Chinese students of Spanish with their lecturer. This research aims to answer the following questions:

1. How do Spanish-major Chinese students show disagreement via email in an academic situation?

2. Which pragmatic strategies are used in a social interaction with an asymmetrical power dynamic (student - teacher)?

To answer these questions, we selected 149 Chinese students majoring in Spanish as a foreign language from Heilongjiang International University. The participants consisted of 130 females and 19 males aging from 20 to 27 with a language proficiency of a B1+ who were studying in their final year. They were all native speakers coming from different regions of China and some of them stayed a year in a Spanish-speaking country. Some of the examples used in this paper 
are transcribed in the Nebrija-WOCAE (Written and Oral Chinese Academic Emails) corpus in SLABank/TalkBank (Rodríguez-Velasco and Liu, 2019). In the pursuit of collecting dissenting emails, a pedagogical framework-based task was designed to elicit the data for this study. The instructions were as followed:

Imagine your lecturer has sent you the following email. You obtained a mark of 4 out of 10 (FAIL) in the final examination for the module of Salón de Conversión [Oral Spanish] and you do not agree with the mark given. Write an email to your lecturer Dr Pedro Rodríguez Torres showing your opinion along with any request you feel is necessary.

To validate the data-collection instruments, a group of 10 second-year students were invited to complete the task. After analyzing the results, we realized that the statement was not clear enough, so the Spanish version was simplified and improved to avoid possible misunderstandings. Then the final version was again shown to several students so they could explain the objective of the task to check understanding. Once the task was understood, it was given to all fourth-year students. The task simulated a situation in which the lecturer has sent to his students an email letting them know that the exam was failed. In this scenario, the subjects were expected to disagree with their lecturer. As our focus is not the analysis of their language expertise, but the study of their pragmatic competence in an academic context and their strategies related to politeness, students were allowed to use their dictionaries and online resources in case they wanted to search for vocabulary, grammar or structures and uses of politeness formulas. To identify their disagreement strategies, a qualitative analysis focused on the content of the main text was performed using MaxQDA. Data was analysed individually by each author and then constrasted once completed in order to validate the results. After the data was identified and validated, the taxonomy from Xuehua's (2006) study was applied, which classifies disagreement in five different strategies: Strategy 1 (direct strategy), Strategy 2 (negative politeness strategy), Strategy 3 (positive politeness strategy), Strategy 4 (hinting strategy) and Strategy 5 (avoidance strategy). However, because this study differs from Xuehua's in that students were asked to reply and to disagree with their lecturer directly, Strategy 5 was removed. This paper does not intend to cite evidence that represents Chinese interactional behavior. Rather, it shows how Spanish-major Chinese students use disagreement strategies in the academic field. 


\section{CHINESE STRATEGIES FOR DISAGREEMENT IN EMAIL COMMU- NICATION}

Results reveal that out of the 149 emails that were collected originally, 14 (9.4\%) did not express disagreement despite the instructions in the heading. As Honglin (2007: 66) noted, this situation might be the case because the Chinese tend to be reverent towards their forbearers and respect their teachers by valuing their work. It seems that some students prefer to make up excuses or lie to their lecturer than to confront him, as can be seen in Table III. These emails have thus been removed, which leaves a total number of 135 emails to analyze.

Table III. Example of omission found in the Spanish corpora written by Chinese students.

\begin{tabular}{|c|c|}
\hline $\begin{array}{c}\text { Example written by Chinese } \\
\text { students }\end{array}$ & English translation \\
\hline $\begin{array}{l}\text { Empecé a repasar medio año antes } \\
\text { del examen, sin cesar. Aunque mi } \\
\text { cumpleaños también estaba dentro de } \\
\text { estos días. Lo sé soy una extrajera en } \\
\text { la clase y sólo estudié } 4 \text { años. Pero in- } \\
\text { tento ser una nativa y todos me dicen } \\
\text { es verdad. Peseo de ganar la beca y no } \\
\text { puedo suspender. Por eso, quería usted } \\
\text { decirme los errores que los tengo en la } \\
\text { examen y enviar los detalles sobre la } \\
\text { nota al grupo de Whatsapp. A través } \\
\text { de estos, podré estudiar más. } \\
\text { (CH-ES_4_36:10) }\end{array}$ & $\begin{array}{l}\text { I started revising incessantly half a year } \\
\text { before the exam. Even if one of those } \\
\text { days was my birthday. I know I am a } \\
\text { foreigner in the classroom and I only } \\
\text { studied for } 4 \text { years. But I try to be like } \\
\text { a native and everyone tells me it's true } \\
\text { (sic). [I wish] to obtain a scholarship } \\
\text { and I can't fail. Therefore, I would like } \\
\text { for you to tell me my mistakes in the } \\
\text { exam and send me the details about } \\
\text { my mark on the Whatsapp group. } \\
\text { Through that, I will be able to study } \\
\text { more. }\end{array}$ \\
\hline
\end{tabular}

In those 135 emails, some sentences were hard to understand, so much that in some parts the meaning was unclear. The lack of vocabulary, and the overall low mastery of the language therefore required an approximate interpretation. This was the case in 20 emails, representing $14.81 \%$ of the corpus. These cases were not

${ }^{2}$ The labels in the examples coincide with those of the WOCAE corpus. CH-ES correspond to the name and language of the corpus, followed by the academic year and the example (_4_36) and, after the two dots, the line of the transcript in which the example is included. However, since the loading of the corpus is still in progress, some example may be missing, but will be visible soon.

${ }^{3}$ The English translation of the Spanish/FL examples does not contain the lexical and grammatical errors of the original student production. 
considered as a strategy, but they deserved mention as they make up for $14.81 \%$ of the examples. For the sake of clarity, some examples are given in Table IV.

Table IV. Examples of unclear sentences found in the Spanish corpora written by Chinese students.

\begin{tabular}{|c|c|}
\hline $\begin{array}{c}\text { Example written by Chinese } \\
\text { students }\end{array}$ & $\mathbf{n}$ \\
\hline $\begin{array}{l}\text { Porque hablo español todos los dias. } \\
\text { Y también me gusta hablar con mis } \\
\text { profesores. Me parece mi pronun- } \\
\text { ciación es correcta. Pudo haber un } \\
\text { error gramatical. Pero no en cuan- } \\
\text { to a una fracción de la mayoría. } \\
\text { ¿Por eso usted puede volver a con- } \\
\text { siderar la fracción de mi? } \\
\text { (CH-ES_4_14:16) }\end{array}$ & $\begin{array}{l}\text { Because I speak Spanish every day. } \\
\text { And I also like to talk to my teach- } \\
\text { ers. It seems my pronunciation is } \\
\text { correct. There could be a gram- } \\
\text { matical error. But not in terms of a } \\
\text { fraction of the majority. So, could } \\
\text { you reconsider my fraction? }\end{array}$ \\
\hline $\begin{array}{l}\text { No sólo necesitamos de vocabulario } \\
\text { bastante, sino también necesitamos } \\
\text { la fluidez del lenguaje en Español } \\
\text { oral, pero estoy triste en este examen, } \\
\text { cero que me voy a jugar bien, } \\
\text { pero todavía no be aprobado el } \\
\text { exmane. } \\
\text { (CH-ES_4_100) }\end{array}$ & $\begin{array}{l}\text { We don't just need enough vocabu- } \\
\text { lary, but we also need the fluency of } \\
\text { language in oral Spanish, but I am } \\
\text { sad in this exam, I think I am go- } \\
\text { ing to play well, but I still haven't } \\
\text { passed the exam. }\end{array}$ \\
\hline
\end{tabular}

Once all the emails had been analyzed, we applied Xuehua's (2006) taxonomy. Table $\mathrm{V}$ shows how many e-mails contain one type of strategy, but since the same text can contain multiple strategies, a more detailed analysis of the strategies is needed. The category "strategy" has 459 occurrences in this corpus, with the distribution and the overall percentage also displayed in Table V. The data shows that senior Spanish-major Chinese students preferred to disagree directly (Strategy 1: $52 \%$ ). Despite being the most face-threatening, this strategy was used in 113 out of 135 emails. Students also employed softened strategies to mitigate the impact of their speech acts. Hinting strategy (Strategy 4) was found to be the most used, with 18\% (66/135 emails), followed by negative politeness strategy (Strategy 2: $7 \%$ in 25/135 emails) and positive politeness strategy (Strategy 3: 5\% in 22/135 emails). 
Table V. Distribution of Strategy 1 to Strategy 4 used by the subjects.

\begin{tabular}{|l|c|c|c|c|}
\cline { 2 - 5 } \multicolumn{1}{c|}{} & $\begin{array}{c}\text { Strategy 1: } \\
\text { Direct } \\
\text { Strategy }\end{array}$ & $\begin{array}{c}\text { Strategy 2: } \\
\text { Negative } \\
\text { Politeness } \\
\text { Strategy }\end{array}$ & $\begin{array}{c}\text { Strategy 3: } \\
\text { Positive } \\
\text { Politeness } \\
\text { Strategy }\end{array}$ & $\begin{array}{c}\text { Strategy 4: } \\
\text { Hinting } \\
\text { Strategy }\end{array}$ \\
\hline Emails (N=135) & 113 & 25 & 22 & 66 \\
\hline $\begin{array}{l}\text { Overall preference } \\
(\mathrm{N}=459)\end{array}$ & 239 & 30 & 25 & 82 \\
\hline $\begin{array}{l}\text { Overall percentage } \\
(\mathrm{N}=100 \%)\end{array}$ & 52 & 7 & 5 & 18 \\
\hline
\end{tabular}

\subsection{Strategy 1. Direct disagreement}

Once we analyzed all the data, we discovered that, as Xuehua (2006: 58) argued, the subjects did not have the skill to employ an indirect and subtle way to express their contrasting ideas. Indeed, it seems that students tend to get to the point by disagreeing directly, questioning their teacher's professionalism, sometimes even threatening him, while Honglin (2007) stated that Chinese students hardly choose a direct refusal speech against their teachers. Most of the subjects studied in this paper directly refused to accept their teacher's result. The analysis shows that, out of 239 times in which Strategy 1 was used, students tend to disagree by choosing direct disagreement (116/239), followed by other types of disagreement (59/239), contradiction (58/239) and counterattack (6/239). The subcategory "other types of disagreement" includes any other kind of disagreement which does not fit in the former subcategories. This includes cases in which the students disagree by implying the teachers's lack of professionalism, for instance by asking him to change his mind on their marks or by asking him to double check their exams. To better understand all categories mentioned above, an example of each subcategory is given in Table VII.

Table VI. Number of times Strategy 1 was used.

\begin{tabular}{|c|c|c|c|c|}
\hline Total & $\begin{array}{c}\text { Direct } \\
\text { disagreement }\end{array}$ & Contradiction & Counterattack & Other \\
\hline 239 & 116 & 58 & 6 & 59 \\
\hline
\end{tabular}


Table VII. Examples of Strategy 1 found in the Spanish corpora written by Chinese students.

\begin{tabular}{|l|l|}
\hline Example written by Chinese students & English translation \\
\hline $\begin{array}{l}\text { Tengo unas preguntas sobre del Español } \\
\text { Oral. No estoy de acuerdo de las no- } \\
\text { tas del Español Oral. Porque describí } \\
\text { dos fotos y hablé muchas palabras conti- } \\
\text { go. Creo que tomar buenas notas sobre el } \\
\text { agree with the marks in the Spa- } \\
\text { nish Oral [exam]. Because I des- } \\
\text { cribed two pictures and talked a lot } \\
\text { of words with you. I think I took } \\
\text { (CH-ES_4_23:10) }\end{array}$ & $\begin{array}{l}\text { good notes about my Spanish Oral } \\
\text { [exam]. }\end{array}$ \\
\hline $\begin{array}{l}\text { Vi las notas que me envió, estoy muy } \\
\text { triste no pasó. Creo que mi nivel debe } \\
\text { ser de 6 } 6 \text { puntos más o menos, pero sólo } \\
\text { tengo 4 puntos. }\end{array}$ & $\begin{array}{l}\text { I have seen the marks you sent me, I } \\
\text { am very sad [because] I didn't pass. } \\
\text { (CH-ES_4_51) } \\
\text { points more or less, but I only got } \\
\text { 4 points. }\end{array}$ \\
\hline $\begin{array}{l}\text { Por eso, te necesito cambiar tu concepción } \\
\text { y también cambiar mi nota. En caso } \\
\text { contrario, yo podré denunciarte. Ne- } \\
\text { cesito justicia. } \\
\text { (CH-ES_4_39:25) }\end{array}$ & $\begin{array}{l}\text { This is why, I need you to chan- } \\
\text { ge your mind and my mark too. } \\
\text { Otherwise, I will report you. I } \\
\text { need justice. }\end{array}$ \\
$\begin{array}{l}\text { Todos esospueden significar que mi nota } \\
\text { es falsa. Espero que la universidad } \\
\text { pueda revisar sus listas de notas, a lo } \\
\text { mejor se registra mal. }\end{array}$ & $\begin{array}{l}\text { All of that can mean that my mark } \\
\text { (CH-ES_4_134) } \\
\text { double check your marking sheet, } \\
\text { maybe it was registered wrongly. }\end{array}$ \\
\hline
\end{tabular}

\subsection{Strategy 2. Negative politeness strategy}

Our results showed that our students do not tend to use deference to avoid causing offense and reducing hostility. Moreover, Strategy 2 was found 30 times in the corpus $(7 \%)$. Students seem to express their disagreement without realizing the positive effects of deference. It seems, as Xuehua (2006: 7) observed, that senior students preferred to use negative politeness strategy to express their opinions objectively without taking their hearer's higher social status into consideration. As can be seen in Table IX, downtoners, lexical and verbal modality or rhetorical questions were some of the mitigating strategies found in the corpus. The term that was most used to mitigate their statements was "please". However, "please" 
was normally used at the end of an imperative clause. This linguistic form, as Economidou-Kogetsidis (2011: 14) describes in her study, always sounds harsh even when a "please" is added. It seems that students believe that the mitigating term "please" has enough strength to lower the effect of their imposition on their teacher. Nonetheless, as Hartford and Bardovi-Harlig's (1996: 59) claim, it is not an efficient enough term to mitigate the force of the imperative. This way of thinking leads our students to a pragmatic failure since their lecturer will probably understand their requests as impositions.

Table VIII. Number of times Strategy 2 was used.

\begin{tabular}{|c|c|c|}
\hline Total & Mitigating & Rhetorical question \\
\hline 30 & 29 & 1 \\
\hline
\end{tabular}

Table IX. Examples of Strategy 2 found in the Spanish corpora written by Chinese students.

\begin{tabular}{|l|l|}
\hline Example written by Chinese students & English translation \\
\hline $\begin{array}{l}\text { Creo que no me debo suspender. Podría } \\
\text { verificar mi nota otra vez y escríbeme un } \\
\text { correo electrónico, por favor. } \\
\text { (CH-ES_4_9:20) }\end{array}$ & $\begin{array}{l}\text { I don't think I should fail. Could } \\
\text { and send me an email, please. }\end{array}$ \\
\hline $\begin{array}{l}\text { Me permito molestarle en una bora } \\
\text { tan inoportuna. Es que tengo alguna } \\
\text { duda sobre la nota examen final Salón } \\
\text { de Conversión. } \\
\text { (CH-ES_4_59) }\end{array}$ & $\begin{array}{l}\text { I have a doubt concerning the } \\
\text { mark in the final exam of Salón de } \\
\text { Conversación. }\end{array}$ \\
\hline $\begin{array}{l}\text { ¿No fui a la clase todos los dias? ¿No } \\
\text { me escucho con atención cuando la } \\
\text { clase? ¿No me acabo la tarea? } \\
\text { (CH-ES_4_71) }\end{array}$ & $\begin{array}{l}\text { Didn't I attend every day? Didn't } \\
\text { finish my homework? }\end{array}$ \\
\hline
\end{tabular}

\subsection{Strategy 3. Positive politeness strategy}

Solving issues via email can be face-threatening, so speakers need to mitigate their requests with politeness. As Brown and Levinson ([1978] 1987) noted, positive politeness prevents the other person's self-image from potential distressful con- 
sequences. Nevertheless, in our results our students have failed to use positive politeness strategies. Strategy 3 was used 25 times (5\%), appearing in 22 emails out of 135 emails. It seems, as Xuehua (2006: 59) observes, that the students were hardly aware of the possibility of using this strategy. Students have failed to use this strategy because the threat to the students' positive face did not hold up to the risk of damaging their academic records. Students therefore tend to employ what Pomerantz (1984) classifies as weak disagreement, which consists in mitigating their disagreement by agreeing totally or partially, or by explaining themselves. As shown in Table XI, students are likely to "praise plus disagree" as a way of expressing appreciation of the teacher's viewpoint before pointing out the unreasonableness of the teacher's notion (Yang, 2009: 334). More examples in Table XI extracted from the corpus show how students employ this strategy.

Table X. Number of times Strategy 3 was used.

\begin{tabular}{|c|c|c|c|}
\hline Total & $\begin{array}{c}\text { Total } \\
\text { agreement }\end{array}$ & $\begin{array}{c}\text { Partial } \\
\text { agreement }\end{array}$ & $\begin{array}{c}\text { Conditional } \\
\text { agreement }\end{array}$ \\
\hline 25 & 6 & 17 & 2 \\
\hline
\end{tabular}

Table XI. Examples of Strategy 3 found in the Spanish corpora written by Chinese students.

\begin{tabular}{|c|c|}
\hline Example written by Chinese students & English translation \\
\hline $\begin{array}{l}\text { He recibido tu correo electrónico, ya } \\
\text { sabia que no paso el examen final } \\
\text { de la asignatura salón de conversa- } \\
\text { ción. } \\
\text { (CH-ES_4_44:10) }\end{array}$ & $\begin{array}{l}\text { I have received your email, I knew } \\
\text { that I didn't pass the final exam } \\
\text { from Salón de Conversación }\end{array}$ \\
\hline $\begin{array}{l}\text { Yo sé no bablé muy bien en el exa- } \\
\text { men oral limito vocabulario y mu- } \\
\text { tios errores. Pero creo que puedo pasar } \\
\text { el examen por lo menos. } \\
\text { (CH-ES_4_123) }\end{array}$ & $\begin{array}{l}\text { I know I didn't speak well in the } \\
\text { oral exam. I have limited vocabu- } \\
\text { lary and [made] a lot of mistakes. } \\
\text { But I think I can pass the exam at } \\
\text { least. }\end{array}$ \\
\hline $\begin{array}{l}\text { Creo que las notas no son altas porque } \\
\text { no puedo expresar correctamente } \\
\text { mis pensamientos. } \\
\text { (CH-ES_4_51) }\end{array}$ & $\begin{array}{l}\text { I think my marks aren't high as I } \\
\text { cannot express my thoughts co- } \\
\text { rrectly. }\end{array}$ \\
\hline
\end{tabular}




\subsection{Strategy 4. Hinting strategy}

As Tuan (2009: 22) indicated, Chinese speakers tend to desist from making direct statements to avoid friction, which is why Strategy 4 was the third most used strategy by our senior students. Compared to Xuehua's results, in which senior students applied this strategy in $1.23 \%$ of the cases, Strategy 4 was employed 82 times (18\%) in 66 out of 135 emails, which made it the second most used strategy. Hinting strategy is not the least employed strategy, as it was in Xuehua's study, but it is perceived by our students as less threatening and more polite when disagreeing with their lecturer. Nonetheless, as Mackiewicz (2005: 366) argues, hint is an utterance that has an "off record," or unexpressed, underlying directive. That underlying notion tends to be used by questioning or expressing doubts about the results of their final exam. As can be seen in Table XII, tengo algunas dudas [I have some doubts] or tengo una pregunta sobre mi examen final [I have a question about my final test] are the two most used expressions employed by our students. These two ways of dissenting reaffirm Yeung's (2000) hypothesis which claims that Chinese prefer to disagree by contrasting each other's opinion

Table XII. Examples of implicit disagreement found in the Spanish corpora written by Chinese students.

\begin{tabular}{|l|l|}
\hline $\begin{array}{l}\text { Example written by Chinese } \\
\text { students }\end{array}$ & English translation \\
\hline $\begin{array}{l}\text { Yo escribo este correo porque tengo } \\
\text { algunas dudas para la nota del } \\
\text { examen final de Español oral. } \\
\text { (CH-ES_4_13:9) }\end{array}$ & $\begin{array}{l}\text { I write this email because I have } \\
\text { some doubts about the mark in the } \\
\text { Spanish final exam. }\end{array}$ \\
\hline $\begin{array}{l}\text { Tengo unas preguntas sobre del } \\
\text { Español Oral. } \\
\text { (CH-ES_4_23:9) }\end{array}$ & $\begin{array}{l}\text { I have some questions about the } \\
\text { Spanish Oral [exam] } .\end{array}$ \\
\hline $\begin{array}{l}\text { Espero que pueda considerar un } \\
\text { poco sobre mi nota para ver si } \\
\text { merezco una nota más alta. } \\
\text { (CH-ES_4_59) }\end{array}$ & $\begin{array}{l}\text { I hope you could consider my } \\
\text { mark in order to see if I deserve a } \\
\text { higher mark. }\end{array}$ \\
\hline
\end{tabular}

Hitherto, the results seem to partially correspond to Xuehua's conclusions, which allege that Chinese students tend to be direct in their disagreement. The scarce use of deference through positive or negative politeness, which may avoid causing offense or reducing hostility, is not due to the student's lack of linguistic 
competence. Indeed, students were able to use dictionaries and online resources to overcome their language proficiency deficit, which leads us to believe that they meant exactly what they said. However, data also revealed that, contrary to Xuehua's results, senior students also choose an indirect style when they need to carry out a dissenting act to avoid coming off as aggressive. Therefore, this behavior denotes that we can safely assume that the directness of their acts was voluntary since the stakes on the students' academic records are too high to risk.

\section{DISCUSSING XUEHUA'S TAXONOMY: WHAT IS LEFT OUT?}

Xuehua's taxonomy could not be applied in some cases in this study. For instance, there were some examples in which students sought to win their lecturer's sympathy either by exhibiting their feelings (i.e. sadness, regret, shame) or by attempting to flatter him. These examples were included in Strategy 5, which was, along with Strategy 4, one of the most used categories, as it was employed 83 times (18\%). This strategy may overlap with other categories, such as Xuehua's Strategy 4 (implicitly expressing disagreement, like hints, and positive comment); moreover, it may not be considered as a dissenting act. However, the quantity and quality of these sentences make them a separate phenomenon that deserves further inquiry.

\subsection{Strategy 5. Exhibiting feelings}

Emotions play a vital role in maintaining social order. For instance, they help regulate social distance, announce intentions, and influence the behavior of others. Because emotions can be both helpful and disruptive, cultures have developed norms that regulate what constitutes desirable and undesirable emotional behaviors (Soto, Levenson and Ebling, 2005: 154). Chinese people are thus distinguished for their civility, politeness, decorum, and have been found to control their negative or strong emotions to maintain harmonious interpersonal relationships (Freshley, 2005; Gao, 2008; Cheng and Tsui, 2009; Liu, 2014). Therefore, the students that took part in this study were expected to moderate their temper in their responses. However, they unexpectedly displayed a wide range of emotions in their emails. Strategy 5 was found in 18\% of the cases and used in 61 out of 135 emails. Most of the students made sure their lecturer knew how they felt about the results, which contradicts the notion that Chinese people avoid checking their tone in personal face-to-face communication even if they are very angry, to avoid discontent. It seems that these students sought to win their lecturer's sympathy or support by showing sadness, regret, or shame. Many expressed their 
shame by asking for forgiveness for failing the exam: Espero que puedas perdonarme por este error [I hope you can forgive me for this mistake (CH-ES_4_72)]; Lo siento por no pasar el examen final [I'm sorry I didn't pass the test (CH-ES_4_49:9)] or Si usted está preocupado, por favor perdóname [If you are worried, please forgive me (CH-ES_4_145)]. They also explicitly expressed anger: De verdad, estoy muy enfadada a causa de este asunto [Really, I'm very angry about this whole thing $(\mathrm{CH}$ ES_4_64)]; ¿Cómo está? No lo sé cómo está de tú, pero estoy mal. Porque no pasé el examen [How are you? I don't know how you are, but I'm in bad shape. Because I didn't pass the test (CH-ES_4_27:10)] or ¿Puedes contarme que aspectos no conformidad? Y tú haces eso me hace muy enojar [Can you tell me what you're not satisfied with? What you did makes me very angry (CH-ES_4_97)]. Flattery was also quite present among the students' responses: Sé que eres un buen profesor, te quiero mucho también [I know you're a good teacher, I love you very much too $(\mathrm{CH}$ ES_4_105)]. More examples can be found in Table XIII. According to the study in anthropology and history, students might have recoursed to flattery because the traditional social order is not grounded in individual emotions and feelings and sensitivities are not regarded as entailing relevant social consequences (Lee, 2016: 2 ). In other words, emotional experiences, however intense or devastating, cannot create, maintain, injure, or destroy social relationships (Potter, 1988: 185-86).

Table XIII. Use of showing feelings found in the Spanish corpora written by Chinese students.

\begin{tabular}{|l|l|}
\hline Example written by Chinese students & English translation \\
\hline $\begin{array}{l}\text { Estoy muy triste últimamente, porque } \\
\text { mi puntuación es muy bajo. } \\
\text { (CH-ES_4_12:22) }\end{array}$ & $\begin{array}{l}\text { I am very sad lately because my re- } \\
\text { sult is very low. }\end{array}$ \\
\hline $\begin{array}{l}\text { A lo mejor, creo que ¿no me quieres? } \\
\text { ¿Soy fea? } \\
\text { (CH-ES_4_38:15) }\end{array}$ & $\begin{array}{l}\text { Maybe, I think... don't you like } \\
\text { me? Am I ugly? Or don't I speak } \\
\text { well? }\end{array}$ \\
\hline $\begin{array}{l}\text { Me siento maltratada. No creo que } 4 \\
\text { sea mi nota. } \\
\text { (CH-ES_4_137) }\end{array}$ & $\begin{array}{l}\text { I feel abused. I don't believe } \\
\text { could be my result. }\end{array}$ \\
\hline $\begin{array}{l}\text { ¿ Usted puede decir las razones por que } \\
\text { queria fallar? Yo estaba ansioso por sa- } \\
\text { ber, la vida de lo contrario no tengo } \\
\text { manera de feliz. } \\
\text { (CH-ES_4_97) }\end{array}$ & $\begin{array}{l}\text { ¿Can you tell me the reasons why I } \\
\text { I cannot find a way to be happy. } \\
\text { [researcher interpretation] }\end{array}$ \\
\hline
\end{tabular}


Although the act of disagreement is not in the same sentence as the display of emotions, it still occurs in the same discourse. This calls into question the limits of studying an act of speech when reducing it to a syntactic structure. Intercultural study is likely to require an understanding of a broader context of the phenomenon that is being analyzed. Paradoxically, in studies with DCT, it seems more logical to consider the entire response of the informant and not only the fragment that contains the verb that denotes dissenting act in itself.

It is possible that this finding is at the base of the category "Possible remarks" proposed by Chen, M. (2006). In which case we would propose the inclusion of a new category, as the display of feelings as a multifunctional strategy. This does not exactly correspond to a traditional definition of "empathy", as it can be used to avoid being empathetic or to mark a greater distance from the teacher.

\section{DISCUSSION}

Social interactions, emailing in this case, are a large part of daily life. As Tuan (2009: 34) claims, people change their behavior depending on the situation, such as the required degree of formality, the topics, the asymmetrical or symmetrical power between participants, or the expectations on the type of conversation they are engaged in. In view of this phenomenon, the purpose of this paper was to analyze how Spanish-major Chinese students show disagreement via email in an academic context and which pragmatic strategies are used in a social interaction with an uneven power dynamic (student - teacher). The data analyzed yielded the following major findings.

When asked to express disagreement, Spanish-major Chinese students prefer to use direct disagreement. Indeed, we found that senior students show disagreement by implying the lack of their teachers's professionalism, contradicting him or retaliating. The fact that they were allowed to use external resources such as dictionaries, grammar books and the Internet, leads us to think that their behavior is not due to their poor vocabulary, but it is rather a way of intentionally making themselves clear. Feelings also have an important role in dissenting acts. It seems that the students want to win their lecturer's support through the display of emotions. These results contradict Gao's (2008) claim that saving face is a characteristic of Chinese culture, where people conceal their bad or strong emotions to preserve a harmonious relationship. On the contrary, it was found that, as Ye (2004: 227) affirms, face is not the key concept in the broader Chinese social pattern. Data revealed that instead of restraining their feelings, some students try to solicit the empathy of their teachers. A possible motive behind this strategy may involve the need to lessen the risk of directly disagreeing. Hinting was also found to be a strategy student used to disagree. Questioning or contrasting the results 
of their final exam were the two most used forms senior students adopted in their disagreement. However, compared to the high number of direct strategies, the number of cases in which hinting strategy was employed conveys that students need a better understanding of the illocutionary force of their speech acts to be able to communicate accordingly.

In response to the second question, Spanish-major Chinese students, as aforementioned, tend to primarily choose Strategy 1 (Direct Strategy) a lot more than any other strategy. Strategy 5 (Emotion Strategy) was also used by the majority, closely followed by Strategy 4 (Hinting Strategy). Strategy 2 (Negative politeness Strategy) and Strategy 3 (Positive politeness Strategy) were the least popular, as can be seen in Table XIV.

Table XIV. Final distribution of disagreement strategies used by the subjects and overall preference and percentage.

\begin{tabular}{|l|c|c|c|c|c|}
\hline & $\begin{array}{c}\text { Strategy 1: } \\
\text { Direct } \\
\text { Strategy }\end{array}$ & $\begin{array}{c}\text { Strategy 2: } \\
\text { Negative } \\
\text { Politeness } \\
\text { Strategy }\end{array}$ & $\begin{array}{c}\text { Strategy 3: } \\
\text { Positive } \\
\text { Politeness } \\
\text { Strategy }\end{array}$ & $\begin{array}{c}\text { Strategy 4: } \\
\text { Hinting } \\
\text { Strategy }\end{array}$ & $\begin{array}{c}\text { Strategy 5: } \\
\text { Emotional } \\
\text { Strategy }\end{array}$ \\
\hline $\begin{array}{l}\text { Emails } \\
(\mathrm{N}=135)\end{array}$ & 113 & 25 & 22 & 66 & 61 \\
\hline $\begin{array}{l}\text { Overall } \\
\text { preference } \\
(\mathrm{N}=459)\end{array}$ & 239 & 30 & 25 & 82 & 83 \\
\hline $\begin{array}{l}\text { Overall } \\
\text { percentage } \\
(\mathrm{N}=100 \%)\end{array}$ & 52 & 7 & 5 & 18 & 18 \\
\hline
\end{tabular}

It is believed that "the asynchronous nature of email might in fact promote appropriately polite messages because writers can take time to construct and revise their messages to optimize their self-presentation" (Biesenbach-Lucas, 2007: 60). Therefore, it was expected that student's messages were characterized by features that reflect greater formality. More specifically, it was foreseen that students' email might exhibit indirectness rather than directness, as well as lexical and syntactic strategies to mitigate the illocutionary force in their disagreement. Nonetheless, results seem to indicate that these senior Spanish-major Chinese students do not have the ability to write status-congruent email messages to faculty. As the WOCAE Corpus shows in TalkBank, where more examples of this study can be found, 
students use a high number of direct strategies mixed with imperative clauses, which makes their communication discourteous. This finding contradicts those of other researchers such as Lather, Jain and Shukla (2010), Yuan (2010) and specifically Ly (2016: 65) who states that "in terms of perception, the Asian informants preferred requests to be expressed rather directly, while criticism and disagreement were preferred when expressed indirectly". It is possible that the preferences of recipients of the communication do not coincide with their behavior as writers in the formal sphere. The issue should also be studied based on the impact of messages written by foreign teachers on Chinese university students.

This behavior leads our students to a pragmatic failure since, as EconomidouKogetsidis (2016: 15) affirms, "such direct and unmodified emails can have a negative effect on participants' evaluation of the personality of the email sender". Therefore, their acts can be understood by their lecturer as an imposition or a threat. Additionally, the lack of deference and the overexposure of their feelings make their speech acts inappropriate for an academic context. The cause of this phenomenon might be the lack of instruction and understanding of the illocutive force in their speech acts. As Chen (2015: 144) mentions, "when writing an email, the writer needs to consider at the same time the purpose of the message, the person addressed to and the pragmalinguistic expressions used to convey the writer's intent". It thus seems essential both to strengthen their sociopragmatic knowledge by educating them in Spanish sociocultural norms and to develop their pragmalinguistic skills to successfully overcome any possible face-threating situation. As a result, an important pedagogical implication of the study is that "teachers must pay more attention to pragmatic knowledge and try to inform students about the appropriate [...] behaviours used by [...] native speakers. It is necessary for students to be aware of [native] socio-cultural norms of speech act realizations" (Zarepour and Saidloo, 2016: 584). Sociopragmatic competence may require the implementation of more intensive bilingual programs, where the foreign language is a means of communication not only with the teacher, but also among peers (Lindholm-Leary, 2016).

\section{CONCLUSION, LIMITATIONS, AND SUGGESTIONS FOR FURTHER RESEARCH}

This research has examined the microstructure of dissenting emails written by Chinese university students of Spanish to a university teacher. It has analysed their pieces in pursuit of the examination of their sociopragmatic knowledge in a digital environment and its adequacy in an academic Spanish context. This paper has focused specifically on the identification of strategies related to the act of disagre- 
ement and has also studied the pragmatic moves related to politeness and level of directness. It has evidenced the need for instruction on how to write culturally acceptable and context-adequate emails and has further exhibited the students' lack of pragmatic competence due to their preference for abrupt and direct language with scarce use of deference and with an overexposure of feelings.

A limitation of the present study concerns the fact that our results need to be treated with caution, as the corpus is too small to represent typical Chinese methods of handling disagreement. It has not the intention to cite evidence in representation of interactional behaviour within the country, but to form a more complete picture of the pragmatic awareness and competence of this particular group. This study was limited in several other ways as well. First, it focused only on the strategies related to disagreement, while other sorts of pragmatic movements related to politeness, such as the (in)formality of their form of address and farewells, were excluded. Second, it was limited regarding the medium (electronic mails) and scope of communication, as it did not compare emails written by Spanish native speakers and non-native speakers. It could also be argued that some of the sentences overlapped into different categories. Due to the pragmatic aspects of language use, some of the examples were inter-related and overlapped in the sense that there was no clear cut-off point to distinguish them as a single unit.

It is hoped that in future a study will emerge in which more pragmatic movements and both native and non-native students can be analysed to support our claims and highlight the strategy patterns used by both groups.

\section{REFERENCES}

Ainciburu, María Cecilia. (2018). El estudio de los géneros académicos en la producción textual en ELE. Journal of Spanish Language Teaching, 5(2), 139-151.

Biesenbach-Lucas, Sigrun. (2006). Making requests in email: Do cyber-consultations entail directness? Toward conventions in a new medium. In: K. BardoviHarlig, C. Felix-Brasdefer and A. Omar. (Eds.). Pragmatics and language learning (pp. 81-108). Honolulu, HI: Second Language Teaching and Curriculum Center, University of Hawai' i.

Biesenbach-Lucas, Sigrun. (2007). Students writing emails to faculty: An examination of e-politeness among native and non-native speakers of English. Language Learning and Technology, 11(2), 59-81.

Brenes-Peña, Ester. (2011). La expresión lingüistica del rechazo: Actos de habla disentivos vs. actos de habla descalificativos. Frankfurt: Peter Lang.

Brown, Penelope and Levinson, Stephen. ([1978] 1987). Universals in language usage: Politeness phenomena. In: E. Goody. (Ed). Questions and Politeness (pp. 56-89). Cambridge: Cambridge University Press. 
Chang, Miao-Hsia; Curran, Jean; Hsu, Yueh-Kuei and Hsu, Chih-Chun. (2016). Do Chinese Students Waffle in Their Apologies? An Exploration into EFL Learners' Emails. In: Y. Chen, DH. Rau, G. Rau. (Eds.) Email discourse among Chinese using English as a lingua franca. (pp. 61-90). Springer, Singapore

Chen, Chi-Fen. (2006). The development of email literacy: From writing to peers to writing to authority figures. Language Learning and Technology, 10(2), 3555.

Chen, Miao-Tzu. (2006). An interlanguage study of the speech act of disagreement made by Chinese EFL Speakers in Taiwan. Unpublished Master's Thesis, Koashiung: National Sun Yatsen University.

Chen, Yuan-Shan. (2015). Developing Chinese EFL learners' email literacy through requests to faculty. Journal of Pragmatics, 75, 131-149.

Chen, Rong; Chunmei, Hu and He, Lin. (2013). Lying between English and Chinese: An intercultural comparative study. Intercultural Pragmatics, 10(3), 375-401.

Cheng, Winnie and Tsui, Amy. (2009). 'Ahh ((laugh)) well there is no comparison between the two I think': How do Hong Kong Chinese and native speakers of English disagree with each other? Journal of Pragmatics, 41(11), 2365-2380.

Claudio-Quiroga, Gloria. (2017). Intercambios educativos entre China y España en la Universidad: Plataforma de acercamiento entre los dos países. Anuario Jurídico y Económico Escurialense, 50, 475-498.

Economidou-Kogetsidis, María. (2011). "Please answer me as soon as possible": Pragmatic failure in non-native speakers' e-mail requests to faculty. Journal of Pragmatics, 43(13), 3193-3215.

Economidou-Kogetsidis, María. (2016). Variation in evaluations of the (im)politeness of emails from L2 learners and perceptions of the personality of their senders. Journal of Pragmatics, 106, 1-19.

Freshley, Dwight. (2005). A crosscultural study of identification of emotions: China and the United States. Intercultural Communication Studies, 14 (1), $171-175$.

Gao, Xuesong. (2008). Teachers' professional vulnerability and cultural tradition: A Chinese paradox. Teaching and Teacher Education, 24(1), 154-165.

Gu, Yueguo. (1990). Politeness phenomena in modern Chinese. Journal of Pragmatics, 14, 237-257.

Gumina, Deena. (2018). Language power and hierarchy: Multilingual education in China. International Multilingual Research Journal, 12(3), 217-219.

Günthner, Susanne. (1993). German-Chinese interactions differences in contextualization conventions and resulting miscommunication. Pragmatics, 3(3), 283-304

Hartford, Beverly and Bardovi-Harlig, Kathleen (1996). "At your earliest conve- 
nience": A study of written student requests to faculty. Pragmatics and Language Learning, 7, 55-69.

Honglin, Li. (2007). A comparative study of refusal speech acts in Chinese and American English. Canadian Social Science, 3(4), 64-67.

Hu, Hsien. (1944). The Chinese concepts of "face". American Anthropologist, 46(1), 45-64.

Hu, Yanjuan; Van Veen, Klaas and Corda, Alessandra. (2016). Pushing too little, praising too much? Intercultural misunderstandings between a Chinese doctoral student and a Dutch supervisor. Studying teacher education, 12(1), 70-87.

Kerbrat-Orecchioni, Catherine. (1997). A multilevel approach in the study of talk-in-interaction. Pragmatics. Quarterly Publication of the International Pragmatics Association (IPrA), 7(1), 1-20.

Lather, Anu; Jain, Shilpa and Shukla, Anju. (2010). Cross cultural conflict resolution styles: An extensive literature review. Asian Journal of Management research, 1, $130-146$.

Lee, Haiyan. (2016). Chinese feelings: Notes on a ritual theory of emotion. The Wenshan Review of Literature and Culture, 9(2), 1-37.

Lindholm-Leary, Kathryn. (2016). Students' perceptions of bilingualism in Spanish and Mandarin dual language programs. International Multilingual Research Journal, 10(1), 59-70.

Liu, Chun. (2014). Chinese, why don't you show your anger? A comparative study between Chinese and Americans in expressing anger. International Journal of Social Science and Humanity, 4(3), 206-209.

Locher, Miriam and Graham, Sage. (2010). Introduction to interpersonal pragmatics. Mouton: Berlin.

Ly, Annalise. (2016). Internal e-mail communication in the workplace: Is there an "East-West divide"? Intercultural Pragmatics, 13(1), 37-70.

Mackiewicz, Jo. (2005). Hinting at what they mean: Indirect suggestions in writing tutors' interactions with engineering students. IEEE Transactions on Professional Communication, 48(4), 365-376.

Mao, LuMing. (1994). Beyond politeness theory: 'Face' revisited and renewed. Journal of Pragmatics, 21, 451-486.

Pomerantz, Anita. (1984). Agreeing and disagreeing with assessments: some features of preferred/dispreferred turn shapes. In: M. Atkinson. (Ed.), Structures of Social Action: Studies in Conversation Analysis (pp. 57-101). Cambridge: Cambridge University Press.

Potter, Sulamith. (1988). The cultural construction of emotion in rural Chinese social life. Ethos, 16(2), 181-208.

Rees-Miller, Janie. (2000). Power, severity and context in disagreement. Journal of Pragmatics, 32, 1087-1111. 
Rodríguez-Velasco, David and Liu, Xiaoxu. (2019). Nebrija-WOCAE (Written and Oral Chinese Academic Emails) Corpus. Retrieved from: https://slabank. talkbank.org/ access/Spanish/Nebrija-WOCAE.html

Sacks, Harvey. (1987 [1973]). On the preferences for agreement and contiguity in sequences in conversation. In: G. Button and J. Lee (Ed.) Talk and Social Organisation. Clevedon (pp. 54-69). England: Multilingual Matters.

Siu, Fiona. (2008). Exploring the pragmatic competence of EFL learners in the production and judgement of formal written requests. Doctoral dissertation. Macquarie University, Australia.

Soto, José; Levenson, Robert and Ebling, Rachel. (2005). Cultures of moderation and expression: emotional experience, behavior, and physiology in Chinese Americans and Mexican Americans. Emotion, 5(2), 154-165.

Tseng, Chia-Ti. (2015). "You must let me pass, please!": An investigation of email request strategies by Taiwanese EFL learners. Journal of ELT and Applied Linguistics, 3(1), 11-28.

Tuan, Jeanne. (2009). An analysis of indirectness in disagreement: a corpus study on intercultural conversations between Taiwanese and Native Speakers of English. Shu-Te Online Studies of Humanities and Social Sciences, 5(2), 13-38.

Walker, Deron. (2011). How to teach contrastive (intercultural) rhetoric: Some ideas for pedagogical application. New Horizons in Education, 59(3), 71-81.

Woodfield, Helen and Economidou-Kogetsidis, Maria. (2010). 'I just need more time': a study of native and non-native students' request to faculty for an extension. Multilingua, 29, 77-118.

Xuehua, Wu. (2006). A study of strategy use in showing agreement and disagreement to others' opinions. CELEA Journal, 29(5), 55-65.

Yan, Chu. (2016). A contrastive pragmatic study of politeness strategies in disagreement between native speakers of English and Chinese EFL learners. Chinese Journal of Applied Linguistics, 39(2), 231-248.

Yang, Robin. (2009). Other-Repair in Chinese conversation: A case of web-based academic discussion. Intercultural Pragmatics, 6(3), 315-343.

Ye, Zhengdao. (2004). Chinese categorization of interpersonal relationship and the cultural logic of Chinese social interaction: An indigenous perspective. Intercultural Pragmatics, 1(2), 211-230.

Yeung, Lorrita. (2000). The question of Chinese indirectness: A comparison of Chinese and English participative decision-making discourse. Multilingua, 19(3), 221-264.

Yuan, Wenli. (2010). Conflict management among American and Chinese employees in multinational organizations in China. Cross Cultural Management: An International Journal, 17(3), 299-311. 
Zarepour, Fatemeh and Saidloo, Masoumeh. (2016). An analysis of Iranian EFL learners' English written requestive emails. Journal of Language Teaching and Research, 7, 579-585.

Zhu, Weihua. (2014). Managing relationships in everyday practice: The case of strong disagreement in Mandarin. Journal of Pragmatics, 64, 85-101. 